\title{
Advances in Agronomic Management in Indian Mustard for Eastern Uttar Pradesh
}

\author{
Akhouri Nishant Bhanu ${ }^{\mathbf{1}}$, Kartikeya Srivastava ${ }^{\mathbf{1}}$ and Rajesh Kumar Singh ${ }^{\mathbf{2}}$ \\ ${ }^{1}$ Department of Genetics and Plant Breeding, Institute of Agricultural Sciences, Banaras Hindu University, Varanasi, India \\ ${ }^{2}$ Department of Agronomy, Institute of Agricultural Sciences, Banaras Hindu University, Varanasi, India \\ *Corresponding Author: Akhouri Nishant Bhanu, Department of Genetics and Plant Breeding, Institute of Agricultural Sciences, Banaras \\ Hindu University, Varanasi, India.
}

Received: April 26, 2019; Published: July 08, 2019

DOI: 10.31080/ASAG.2019.03.0566

\begin{abstract}
Rapeseed-mustard crops are one of the most important annual oilseed crop cultivated in India. Among the rabi oil seed crops cultivation of rapeseed and mustard is a common practice throughout Uttar Pradesh. Scope for area expansion is limited so production would be increased only through increase in productivity per unit of land. Growing Indian mustard turns out to be less remunerative to the farmers under marginal resource situation. This leads to immense gap between demand and supply of rapeseedmustard in India. In this situation, there is a need of soil testing and site-specific nutrient management to advance the existing yield level at farmer's field. The production and productivity of rapeseed-mustard in eastern Uttar Pradesh may be enhanced at least twice if proper varieties and information on recommended agronomic practices such as effective management of natural resources, integrated approach to plant-water, nutrient and pest management and extension are made available to the farmers. In this review paper, the progress in correct land and seedbed preparation, seed quality and sowing, planting technique, integrated approaches for nutrient, weed, disease and pest management, plant growth regulators and so forth to meet the ever increasing requirement of rapeseed-mustard in the country have been discussed. The overall knowledge is being described hereunder in different vital sections.
\end{abstract} Keywords: Rapeseed-Mustard; Indian Mustard; Crop

\section{Introduction}

Rapeseed-mustard belonging to family cruciferous (syn. Brassicacae) is the third important oilseed crop grown in the world after soybean (Glycine max) and palm (Elaeis guineensis Jacq.) oil. India is an important rapeseed-mustard growing country in the world, occupying the fourth position in its area and production after Canada, China and European Union. Out of the seven edible oilseed cultivated in India, contribution of rapeseed-mustard (Brassica spp.) is $28.6 \%$ in the total production of oilseeds [1]. In India, it is the second most important edible oilseed after groundnut which shares $27.8 \%$ in the India's oilseed economy [1]. Out of the total cropped area in India, the share of oilseeds is $14.1 \%$ in which rapeseed-mustard accounts for 3\%. The overall production of rapeseed-mustard and its oil is around $38-42 \mathrm{mt}$ and $12-14 \mathrm{mt}$, respectively. Contribution of India in world acreage and production is $28.3 \%$ and $19.8 \%$, respectively. India produces around $6.7 \mathrm{mt}$ of rapeseed-mustard with significant contribution in world rapeseedmustard industry. The rapeseed-mustard broadly comprises of Indian mustard, yellow sarson, brown sarson, raya, and toria. In the recent past, the area under Indian mustard is on the increase at the cost of other Brassicas due to its higher productivity and tolerance to biotic and abiotic stresses. Rapeseed cultivation is confined only to northern India because of late maturity and shattering of pods owing to high temperature prevailing during harvest in FebruaryMarch. Indian mustard (Brassica juncea (L.) Czernj. and Cosson) is primarily cultivated in Rajasthan, Uttar Pradesh, Haryana, Gujarat and Madhya Pradesh. Besides this, it is also cultivated under some nontraditional areas of South India including Andhra Pradesh, Karnataka and Tamil Nadu. 
In U.P it is grown in 0.82 mha with production of $0.90 \mathrm{mt}$. The average productivity in U.P is $1141 \mathrm{~kg} \mathrm{ha}^{-1}$, which is $3.6 \%$ lower than the national average productivity [2]. In Uttar Pradesh, there is a down fall of area and production since 1980-81, though productivity has increased from $540 \mathrm{~kg} \mathrm{ha}^{-1}(1980-81)$ to $1015 \mathrm{~kg} \mathrm{ha}^{-1}$ (2015-16). This downfall might be due to shifting from sole crop to mixed cropping of mustard, particularly in eastern part of Uttar Pradesh, rabi crop competition especially with wheat and lack of remunerative mustard based cropping system. The production and productivity of mustard in this area may be enhanced at least twice if proper varieties and recommended agronomic practices are made available to the farmers. Keeping the above point under consideration, this review has been prepared giving proper emphasis on the agronomic practices that should be well thought-out for enhancement in production and productivity of Indian mustard in Eastern Uttar Pradesh.

\section{Adaptation and soil}

Indian mustard is a cool season crop and is cultivated in the tropical as well as in the temperate zones. It requires comparatively cool temperature and a dry harvest period. In India, it is grown mainly in Rabi (winter) season from September-October to February-March. Indian mustard is reported to withstand annual precipitation of 50 to $420 \mathrm{~cm}$, annual temperature of 6 to $27^{\circ} \mathrm{C}$, and $\mathrm{pH}$ of 4.3 to 8.3. However, it performs best in the soil with a neutral $\mathrm{pH}(\mathrm{pH} 7)$ but can tolerate alkaline above $\mathrm{pH} 7$ and slightly saline soils. $\mathrm{t} 15-20^{\circ} \mathrm{C}$ temperature, Rapeseed-mustard has efficient photosynthetic response because of presence of $\mathrm{C}_{3}$ pathway for carbon assimilation. It prefers well aerated soils that do not become waterlogged. It is grown under a wide, range of soil conditions varying from sandy loam to clay loam soils but thrives best on light loam soils. Since the rapeseed-mustard requires less water (24-40 $\mathrm{cm})$, it is suitable in rainfed cropping systems.

\section{Improved varieties for Eastern Uttar Pradesh}

In India, for mustard cultivation areas, enormous unevenness exists in the climatic and edaphic conditions prevails. Therefore, there is a need for selection of best fitting cultivars for enhancing the productivity. Area specific short duration cultivars can be preferred in regions where effective growing seasonal length is short. It has been visualized that improved varieties stabilizes seed yield and oil content (low erucic acide and glucosinolate content) by providing better tolerance against major biotic and abiotic stresses.
The varieties developed for eastern Uttar Pradesh areas at different centers of rapeseed-mustard research under the aegis of Directorate of Rapeseed-Mustard Research at Bharatpur (Rajasthan) are very promising. Different varieties for this area under different sowing conditions are proposed.

Early sowing (last week of September to first fortnight of October): Narendra Ageti Rai 4, Kanti, Pusa Mustard-25, Pusa Mustard-27 (EJ-17); Timely sowing (within October): Varuna (T-59), Kranti, Rohini, Maya, Pusa Bold, Urvashi, Narendra Swarna Rai 8 (Yellow), Basanti (Yellow), Krishna, RH 749, RGN-73, Albeli-1; Late sowing (within November): Ashirwad, Vardan, NRCHB 101, Swarna Jyoti; Rainfed condition: Varuna, Vaibhav; Intercropping: Vardan; Salt-affected soils: NDR 8501, CS 52, CS 54, CS 58; Hybrids: NRCHB 506, DMH-1, PAC-432.

\section{Land and seed bed preparation}

To ensure high germination percentage a fine seed bed is essential. A uniform, firm and moist seedbed that provide better seed-soil contact, rapid moisture absorption and uniform germination are the prerequisite for mustard seedbed. Since tillage affects both crop growth and grain yield, various tillage systems have been followed such as: (i) Conventional tillage: moldboard ploughing followed by disc harrowing; (ii) Reduced tillage: disc ploughing followed by disc harrowing and (iii) Complete zero tillage: crop is sown under uncultivated soil [1]. Asoodari., et al. [3] suggested that minimum tillage, with or without straw, enhances soil moisture conservation and moisture availability during crop growth which results in increased root mass, yield components and seed yield. Zero tillage conserves better moisture in the soil profile all through the early growth period and thus may be preferred in mustard. It has been observed that Subsequent release of conserved soil moisture regulates proper plant water status, soil temperature, lower soil mechanical resistance that leads to better root growth and higher grain yield of mustard [4]. However, to achieve success with minimum or zero tillage, even distribution of crop residues and evenly distributing residue is required that must create a firm, moist and uniform seedbed. The growth of plant and dry matter biomass of mustard in case of zero tillage will be on the higher side if $\mathrm{N}$ fertilizers are used in appropriate quantity [5].

\section{Seed and sowing}

Under low temperature and radiation regime, seed germination, seedling vigour, fine root growth and development, early stem 
elongation, speedy ground covering ability and early flowering are major yield determining characters. A good quality seed grown at suitable time along with maintaining an optimum plant population facilitate in exploiting these traits successfully in mustard.

- $\quad$ Seed Priming: Seed priming process is a pre-sowing strategy that exposes seeds to a certain solution for a certain period that allows partial hydration, but radicle emergence does not occur [6]. To achieve healthy plant growth seed treatment is a useful method. It generally enhances germination rate and plant performance. In mustard, seed priming through controlled hydration and dehydration augments early germination in a lesser amount of time, even in compact or compressed soil [7]. The germination gets better when mustard seeds are soaked for 4 hours in $0.025 \%$ pyridoxine hydrochloride solution (aqueous). The combination of pyridoxine, $\mathrm{N}_{60} \mathrm{P}_{20}$ and $\mathrm{N}_{15} \mathrm{P}_{5}$ as top dressing speeds up the crop performance by increasing seed and oil yield [8]. The seeds of different varieties show differential response for imbibitions. The seed which has high rate of imbibition gives advantage to germinate early in comparison to others. Such drastic difference in rate of imbibition is significant under abiotic stress conditions specifically drought and temperature abnormalities.

- Sowing: The time of sowing vary with agro-ecological conditions. The time of sowing is a very important nonmonetary input to obtain higher yield of Indian mustard. Production efficiency of different genotypes significantly varies under different sowing time. The sowing time of rapeseed-mustard is very much influenced by the soil temperature and moisture in different zones of the country. Likewise, time of sowing influences the phenology of plants via temperature and heat unit. Higher yield can be achieved by timely sowing as this will provide suitable environment required for different growth stages. Though different varieties have a differential response to date of sowing, generally, the month of October is preferred for sowing the seeds for obtaining higher yield in eastern Uttar Pradesh. Delay in sowing results in poor growth, low yield, and oil content whereas, date of sowing also influences the incidence of insect-pest and disease.

- $\quad$ Planting Technique: Land resources, soil condition, and level of management determine the sowing technique. Sowing techniques mostly practiced in mustard are broadcasting, line sowing, ridge and furrow method and broad bed and furrow method. Areas where higher soil moisture prevails, broadcasting followed by light planking gives early germination and growth. Likewise, in area of normal and conserved moisture condition, seed should placed in moist horizon under line sowing turns out to be favorable. Transplanting of mustard has also been reported thereby saving time, and resources [1]. It has been observed that transplanting reduces maturity time and offers higher seed yield.

It is advisable not to use same field continuously for the production of good quality seeds. In mustard, the recommended spacing is $30 \times 10 \mathrm{~cm}$ and $45 \times 10 \mathrm{~cm}$ for varieties and hybrids, respectively. Four to five kilogram seed should be sown in rows of $45 \mathrm{~cm}$ at a depth of 2.5 to 3.0 centimeter [9]. When sown in mixed cropping, 1.5 to $2 \mathrm{~kg}$ seed per hectare is adequate. Sowing could be done either behind the plough or through seed drill. Before sowing, seed should be treated with thiram or captan @ $2.5 \mathrm{~g} \mathrm{~kg}^{-1}$ seed. Intercropping or mixed cropping Mustard can be successfully grown as an intercropped with chickpea (1:3 row ratio), or with wheat (1:9 or 2:10). It is also grown as a mixed crop with wheat, barley, peas, lentil etc. The intercropping system has demonstrated an increase in the total productivity per hectare.

\section{Fertilizer management}

Adequate nutrient supply enhances the yield of seed as well as oil by improving the setting pattern of siliquae on branches, number of siliquae plant ${ }^{-1}$, length of silquae and other yield characters [10]. Recommended dose of fertilizers (RDF) for different zones varies with climatic condition, soil type, time, and type of cropping system practiced. The response of fertilizers however, varies with the water available to crop. It is a well-known fact that in oilseed Brassicas, among the various imputs used in the package of practices, the fertilizer application alone contributes to almost half of the increase in seed yield. Fertilizers are expected to contribute $40-75 \%$ of the increase in yield brought about by adoption of full package of improved practices. For obtaining good yield normal fertilizer dose recommended is $120 \mathrm{~kg}$ nitrogen, $60 \mathrm{~kg}$ phosphorus and $40 \mathrm{~kg}$ potash per hectare. Reager., et al. [11] recommended that split application of total nitrogen in three equal doses one-each as basal, second after first irrigation and remaining one-third after second irrigation results in maximum increase in yield and yield attributes of Indian mustard in comparison to two split doses. It must be noted that top dressing of $\mathrm{N}$ fertilizers should be done immediately after first irrigation and there should not be any delay in first irrigation, as these results in yield reduction of mustard crop.

Rapeseed-mustard has the highest requirement of sulphur among the oilseed crops [12]. Sulphur supports in oil synthesis and

Citation: Akhouri Nishant Bhanu., et al. "Advances in Agronomic Management in Indian Mustard for Eastern Uttar Pradesh". Acta Scientific Agriculture 3.8 (2019): 70-79. 
is a vital element of seed protein, amino acid, enzymes, glucosinolate as well as chlorophyll formation [13]. Experiments have revealed that employment of sulphur in mustard crop under irrigated and rainfed conditions increases the yield by 12 to $48 \%$ and by 17 to $124 \%$, respectively [14]. In terms of agronomic efficiency, the yield of mustard enhances by $7.7 \mathrm{~kg}$ per kilogram of sulphur application [15].

In addition, mustard is highly sensitive to micronutrient deficiency, particularly zinc and boron. The harvest index (HI) gets significantly affected by zinc. The seed yield increases up to $8.5 \%$ on application of $\mathrm{ZnSO}_{4} @ 12.5 \mathrm{~kg} \mathrm{ha}^{-1}$. Application of zinc has a significant effect on the harvest index (HI). In zinc and sulphur deficient soils, application of $25 \mathrm{~kg}$ zinc sulphate and 20-40 kg sulphur per hectare, respectively could be valuable. To satisfy the requirement of sulphur, single superphosphate (SSP), ammonium sulphate and zinc sulphate or potassium sulphate can be applied as per availability. Nitrogen and sulphur provide complementary effects on yield and nutrient content and the desired $\mathrm{N}: \mathrm{S}$ ratio in the seed is 7.5 percent. The magnitude of response to fertilizers under rainfed conditions can be enhanced by making proper application of fertilizers and following the practices of inter-cultivation.

Improvement of overall soil health and reduction in evaporation losses of soil moisture can be achieved by using bulky organic manures. Different organic sources as such as green manure (clusterbean and Sesbania), mustard straw $\left(3 \mathrm{tha}^{-1}\right)$ and vermicompost (2.5-7.5 $\left.\mathrm{t} \mathrm{ha}^{-1}\right)$ can be applied as per the availability and field condition. However, among all these, Sesbania green manuring has revealed superior mustard yield and enhanced soil condition (AICRP-RM, 2006).

Biofertilizer have been used as a component of integrated nutrient management and are inoculants or preparation containing micro-organims that supply nutrients mainly nitrogen and phosphorus. Growth promoter formulations like bioforce and biopower helps to augment water and nutrient absorption from the soil. Application of $25 \mathrm{~kg}$ Biopower and Bioforce @1L 500 litres $^{-1}$ along with RDF (80: 40: 0) at flowering and pod filling stage offers appreciably higher yield in mustard. It has been suggested that foliar spray of Bioforce @ $2 \mathrm{~mL} \mathrm{~L}^{-1}$ at flowering and siliqua formation stage enhances seed yield. Similarly, application of $10 \mathrm{t}$ FYM ha $^{-1}$ along with RDF improves physical condition of soil physical by improving aggregation, increased saturated hydraulic conductivity, and reducing bulk density and penetration resistance of the surface soil [16].
Thinning and inter-culture

Low density allows individual plants tend to branch and utilize the available nutrients and space, and siliqua extend towards the lower part. Thus, to maintain plant to plant distance of $10-15 \mathrm{~cm}$ and to overcome crowding effect and to maintain an optimum plant stand of 25-30 plants ha $^{-1}$, the crop should be thinned out 15-20 days after sowing. Interculture should be followed 20-25 days after sowing to eradicate weeds and to conserve moisture. Anti-transpirants like PMA or Kaoline increases the yield as well as water use efficiency of the crop under dry land conditions. Similarly, foliar application of $0.1 \%$ Cycocel (CCC) results in significant increase in seed yield [17].

\section{Water management}

Rapeseed-mustard crop is sensitive to water scarcity. The water requirement for growing a good mustard crop usually varies between 300 to $400 \mathrm{~mm}$ year-1. The IW/CPE ratio of 0.6 is optimum for the water use efficiency. In mustard, two irrigations, one at flowering stage and at siliqua formation stage increases seed yield upto $28 \%$ under rainfed conditions [18]. Gangasaran and Giri [19] reported that two irrigations given at pre-flowering and pod-filling stages increases seed yield by $33 \%$ in comparison to unirrigated crops. However, irrigation at vegetative and pod formation stages provides highest advantage. Therefore, in general, two irrigations one at 30-35 days after sowing and second at 55 to 60 days after sowing must be given to the mustard crop.

In case of poor water quality, certain treatment and management of quality of irrigation water is needed before being utilized for crop production. It has been reported that irrigation with increased salinity water applied at pre-sowing and flower initiation diminishes the plant height, branching pattern, and pod formation [20]. The dry matter yield decreases drastically with saline water (12 and $16 \mathrm{dS} \mathrm{m}^{-1}$ ) if applied at pre-sowing or afterward. Application of saline irrigation at the pre-flowering stage or afterward leads to decrease of the grain yield by means of $50 \%$ and $70 \%$, respectively. To overcome the ill effects of saline water proper $\mathrm{N}$ management is critical. Majumdar [21] suggested that these problems can be overcome by application of nitrogen with saline water.

\section{Weed management}

Weeds cause alarming reduction in crop production that may range from $15-30 \%$ to overall failure in mustard yield [1,22,23]. Weeds compete with crop plants for water, space, light and nutri- 
ents. Weed competition in mustard crop is more serious in early stages because crop grows slowly during the first 4-8 weeks after sowing. However, the critical period is $15-40$ days. Therefore, to improve the nutrient use efficiency and ultimately the yield, timely and proper control of weed is indispensable. Major weed flora infesting the Mustard crop are: (i) Monocots: Avena fatua, Cynodon dactylon, Cyperus rotundus, Phalaris minor; (ii) Dicots: Anagallis arvensis, Asphodelus tenuifolius Chenopodium album, Fumaria parviflora, Lathyrus aphaca, Melilotus alba, Melilotus indica and Vicia sativa. Apart from this, Broomrape (Orobanche) is an alarming parasitic weed of rapeseed-mustard. On an average, Broomrape weed infestation causes $28-30 \%$ reduction in Indian mustard yield. Amongst Orobanche spp., O. aegyptiaca is one of the most disturbing parasitic weed which causes rigorous yield and quality reduction in rapeseed-mustard. To control Orobanche, bioagents such as Phytomyza orobanchia and fungi such as Fusarium oxysporum sp. orthoceras are found to be useful.

The traditional practice of hand or mechanical weeding once during early stages of crop growth i.e., 25-30 days after sowing (DAS) is not sufficient as new flushes of weeds appears after every mechanical weeding, irrigation and winter rainfall re-infest the crop and most importantly they take away major portion of the nutrients and moisture from the soil. For effective weed management, two hand weeding are generally required. The first should be done 25 to 30 days after sowing (i.e. at fourth leaf stage) and the second at 45-50 days after planting. Wherever hand weeding is not possible or is uneconomical, use of herbicide is recommended. Fluchloralin at the rate of 1 to $1.25 \mathrm{~kg}$ a.i. ha ${ }^{-1}$ as pre-plant incorporation or spraying of pendimethalin @ $1.25 \mathrm{~kg}$ a.i. ha ${ }^{-1}$ (preemergence) could be effective in the management of weeds. Oxadiaryl @ 0.09 kg a.i. ha ${ }^{-1}$ or oxyfluorfen @ 0.15 kg a.i. ha ${ }^{-1}$ as pre-emergence can also be applied. The application of isoproturon @ 1 kg a.i. ha ${ }^{-1}$ is beneficial in wheat + mustard mixed cropping.

Integrated weed management practice for managing weeds in rapeseed-mustard can also be followed. Some of the useful practices have been listed below:

1. Pendimethalin (2 DAS) at $0.75 \mathrm{~kg}$ in combination with hand weeding once at 30 or 40 DAS

2. Pre-emergence of pendimethalin at $1.0 \mathrm{~kg} \mathrm{ha}^{-1}$ followed by hand weeding at 30 DAS

3. Pre-plant incorporation of fluchloralin at $1.0 \mathrm{~kg} \mathrm{ha}^{-1}$ supplemented with one hand weeding at 40 DAS
4. Pre-plant incorporation of fluchloralin at $0.75 \mathrm{~kg} \mathrm{ha}^{-1}$ followed by hand weeding at 30 DAS

5. Pre-emergence application of isoproturon at $1.0 \mathrm{~kg} \mathrm{ha}^{-1}$ along with interculture once at 30 DAS

6. Pre emergence application of oxyfluorofen $250 \mathrm{~g} \mathrm{ha}^{-1}$ followed by one hand weeding at 30 DAS

Response to plant growth regulators

Plant Growth Regulators (PGRs) mitigate abiotic and biotic stresses by favorably affecting various physiological, metabolic, structural and other plant processes [24-26]. In Brassica spp., indeterminate plant growth habit, pod shattering and lodging are the most noteworthy and usual constraints in accomplishing utmost seed yields. Seed loss prior to or during harvest because of shattering of fruits is directly correlated with hormonal imbalances and poor development of lignified cells in the fruit wall. In addition, seed quality and yield is severely affected by lodging of the crop which the consequence of decreased photosynthesis, increased disease intensity, improper drying and lessen harvest efficiency. In such cases, plant growth regulators can be used effectively to overcome these issues that will consequently aid to yield enhancement [27]. Brassinosteroids (BRs), a plant growth regulator that occurs ubiquitously are assumed to function as a "master switch" in biotic and abiotic responses [28]. Among BRs, Brassinolide (BL) is the most bioactive form of the growth-promoting plant steroids [29,30]. 24-epibrassinolide (EBL) and 28-homobrassinolide (HBL) are the other two biologically active brassinosteroids, being widely used [31].

BRs play a pivotal role in the growth and developmental processes throughout the plant life cycle, including germination, root and stem elongation, floral organ elongation and senescence, pollen tube growth, root inhibition, xylem differentiation and regulation of gene expression, regulate the differentiation of the tissue, raise the ratio of fruit bearing and increase the unit weight, etiolation and reproductive development $[32,33]$. In addition, they play a vital role in increasing adaptation to diverse environmental stresses such as light, low or high temperature, drought, salt stress, heavy metal stress, herbicidal injury, and pathogen attack [34]. It has been observed that application of BRs leads to accumulation of maximum total dry matter in comparison to any other treatment at physiological maturity [31]. Foliar application of dilute aqueous solution of BL improves the yields in wheat and mustard [35]. Application of

Citation: Akhouri Nishant Bhanu., et al. "Advances in Agronomic Management in Indian Mustard for Eastern Uttar Pradesh". Acta Scientific Agriculture 3.8 (2019): 70-79. 
HBL and EBL significantly increases yield in mustard [36]. Different mode of HBL application as aqueous solution to the foliage of mustard or EBL, in association with GA3 resulted in enhanced photosynthetic rate $[37,38]$. Moreover, the study showed that HBL can be used to minimize the loss of yield in mustard caused by water deficits (Fariduddin., et al. 2009).

Spray of $\mathrm{GA}_{3}$ at 40DAS leads to better NPK accumulation thus helps in maximizing yield [39]. Application of Mixatalol (a mixture of long aliphatic alcohols varying in chain length from $\mathrm{C}_{24}$ to $\mathrm{C}_{32}$ ) to Brassica plants as foliar spray leads to increase in secondary and tertiary branching with consequent enhancement in seed yield through increased number of infloresence and siliquae plant-1. It also increases total dry matter of plants, partitioning coefficient, and harvest index. Mixtatol treated plants exhibits higher content of starch, protein, and oil in seeds [40].

Disease management

In rapeseed-mustard, Alternaria blight (Alternaria brassicae), white rust 9 (Albugo candida), downy mildew (Hyaloperonospora parasitica), Sclerotinia stem rot (Sclerotinia sclerotiorum) and powdery mildew (Erysiphe cruciferarum) are the most important one. These diseases lead to a crop loss of about $10-75 \%$ depending upon its severity under favourable conditions. The environmental factors congenial for the development and spread of different diseases in epidemic form are temperature $12-25^{\circ} \mathrm{C}$ with relative humidity 70 percent for Alternaria blight, temperature $15^{\circ} \mathrm{C}$ with relative humidity $70 \%$ for white rust and downy mildew and temperature $16-28^{\circ} \mathrm{C}$ with 60 percent relative humidity for powdery mildew. For the management of these diseases, crop rotation and crop sanitation may be practiced. Genotypes resistant to major diseases such as Krishna and Kranti may be used for planting in disease prone areas.

The control measures for different diseases are listed below:

- $\quad$ Alternaria blight: The crop should be sprayed 3-4 times at 10 - 15 days with Dithane M-45 (0.2\%) or Difolatan $(0.2 \%)$ when environmental conditions are favorable for the disease. If there is dry weather with least dew period farmers are advised not to spray the fungicide.

- White Rust: Destroy previous year crop debris, Spray Ridomil MZ 72 @ 0.1\% on first appearance of the disease. Repeat after 10-15 days interval if needed.
- $\quad$ Sclerotinia Stem Rot: Rotating with non host crops like wheat, barley, rice and maize. Timely sowing between October 10-25. Soil application of T. viride/T. harzianum @ $2.5 \mathrm{~kg} \mathrm{ha}^{-1}$, parasitize sclerotia of the pathogen in the soil. Spray Carbendazim @ 0.1\% twice during the flowering period at 20 days interval.

- $\quad$ Damping off seedling: Treat the seed with the systemic fungicide like Carbaxin, or carbendazim $2 \mathrm{~g} \mathrm{~kg}^{-1}$ of seed. While treating the seed care should be taken so as all the seed must receive the chemical. In present days, bio priming and seed treatment with the Trichoderma is recommended. One should be clear that Trichoderma offer protection to seed against externally seed borne pathogen.

- Downy Mildew: At the seedling stage, seed treatment with Apron 35 SD (metalaxyl) @ $6 \mathrm{~g} \mathrm{~kg}^{-1}$ seed. Spray of Dithane M-45 (0.2\%) also gives favorable response.

- $\quad$ Powdery mildew: Spray Sulfex $(0.2 \%)$ or Karathane $(0.1 \%)$.

\section{Pest management}

The major pests of mustard are mustard aphids, saw fly, painted bug etc.

\section{Mustard Aphids [Lipaphis erysimi (Kalt.)}

Mustard aphid infestation in rapeseed-mustard is the most severe one. Aphids are highly active in plains all through November to March. It is small, pearl shaped insect which has soft, delicate and fragile body. Nymphs and adults, both suck the cell sap from various plant parts such as inflorescence, leaf, stem, pods etc. which leads to curly appearance of leaves. In case of severe infestation stunted growth and drying of plant occurs which results into inadequate seed set or no pod formation. Honeydew secreted by aphids is accountable for formation of "sooty mould" (a black fungus) that hinders the process of photosynthesis and may reduce the market value of mustard. The mustard aphid reduces the yield from 9 to 95 percent [41]. The economic threshold (ETL) of this insect pest is infestation of 40 aphids per $20 \mathrm{~cm}$ length of the twig on the top portion of the central shoot or infestation of 30 percent plants.

- Cultural Control: Seeds of early maturity varieties should be sown in the first week of October that makes the mustard crop free from aphid attack due to asynchronisation of peak activity of the pest with vulnerable stage of crop. Split application of recommended nitrogenous fertilizer is also advisable to reduce the pest menace. 
- Biological Control: Four natural enemies viz., Chrysopids, Chrysopa carrnea and Chrysopa scelestes @ 50,000 eggs ha ${ }^{-1}$, lady bird beetles i.e., Coccinella septumpunctata, Menochilus sexmaculata etc., predate on aphids and reduce their population successfully. Neem seed kernel extract (NSKE) @ 1 L $10 \mathrm{~L}^{-1}$ water is also found to be very effective in controlling mustard aphid [41].

- Chemical Control: Selective use of pesticides at right stage of crop with proper method of application on the basis of economic threshold level and abundance of natural enemies effectively retards the pest severity. Two-three sprayings at 10-15 days interval of insecticides viz., Chlorpyrifos $20 \%$ EC @ $200 \mathrm{ml}$ in 200-400 L of water acre $^{-1}$, Dimethoate 30\% EC @ $264 \mathrm{ml}$ in 200-400 L of water acre ${ }^{-1}$, Methyl parathion 2\% DP @6000 g acre $^{-1}$, Imidachloprid 17.8 SL @ $100 \mathrm{ml} \mathrm{ha}^{-1}$, Oxydemeton-methyl 25\% EC @ $400 \mathrm{ml}$ in 200-400 L of water $\mathrm{acre}^{-1}$, Phosphamidon 40\% SL @ $200 \mathrm{ml}$ in $200 \mathrm{~L}$ of water acre $^{-1}$, Thiamethoxam 25\% WG @ 20-40 g in 200-400 L of water acre $^{-1}$ produces promising results. Application of granular insecticides i.e., Phorate 10\% CG @ $4000 \mathrm{~g} \mathrm{acre}^{-1}$ at the time of sowing also decreases pest menace during the early stage of the crop.

\section{Mustard sawfly [Athalia lugens proxima (Klug)]:}

It appears in October and its activity is peak during November. Adult saw fly is orange yellow in colour having black head and legs whereas the larvae are yellowish green to dark green with five lateral strips. They mostly damage the leaves by making uneven holes and prefer to attack when the crop is in early vegetative phase i.e. seedling stage to three to four week old. The grubs prefer the young growing leaves and make holes and skletonise the leaves, thus considered to be very destructive.

- Cultural control: Practices such as summer ploughing to destroy the pupae, clean cultivation, early sowing, collection and destruction of grubs of saw fly in morning and evening, application of irrigation in seedling stage for saw fly management because most of the larvae die due to drowning effect should be followed.

- Biological control: Perilissus cingulator (larval parasitoids) and Serratia marcescens infecting the saw fly larvae can be used. Apply bitter gourd seed oil emulsion as anti- feedant.

- Chemical control: Spray Dimethoate 30\% EC@264 ml in 200-400 L of water acre ${ }^{-1}$, Quinalphos 25\% EC @ 480 $\mathrm{ml}$ in 200-400 L of water acre ${ }^{-1}$, Malathion EC 50\% EC @ $600 \mathrm{ml}$ in 200-400 L of water acre ${ }^{-1}$. Apply Imidacloprid 70\% WS @ 700 g $100 \mathrm{~kg}^{-1}$ seeds, Methylparathion 2\% DP@6000 g acre-1.
Painted bug: Bagrada hilaris (Burmeister) (Hemiptera: Pentatomidae)

Painted bug cause serious damage in mustard. Adult bugs are attractive, grey/dark brown/black in colour with many orange/ brownish spots on their dorsal side. The colour of first and second instar nymph is bright orange whereas it is red for third and fourth instar. Both adults and nymphs attack the leaves and shoots where they suck the cell sap. The leaves turn white in colour and at the same time wilting occurs which on further progression causes whole plant drying.

- $\quad$ Cultural control: Deep plough the soil to destroy eggs of painted bug. Early sowing can be done to avoid pest attack. Crop should be irrigated in IV week after sowing to reduce pest attack. Threshing of the harvested crop should be done quickly.

- Biological control: Bio-control agents such as Alophora spp. (tachinid fly) parasitizes eggs of painted bugs.

- $\quad$ Chemical control: Spray Dichlorvos76\% EC @ 250.8 $\mathrm{ml}$ in 200-400 L of water acre ${ }^{-1}$, Imidacloprid 70\% WS @ 700 g $100 \mathrm{~kg}^{-1}$ seed. Apply Phorate 10\% CG @ 6000 g acre $^{-1}$.

The time of sowing and pesticide interaction is also an important issue to be considered for management of disease and insect pest in advanced stages of crop. The crop is liable to get affected by disease and pest more severely under late sown condition. Excess fertilizer application in late sown condition should be avoided. In such case, crops can be protected from major diseases and aphid by spraying the crop with Ridomil MZ 72 WP during flowering to early pod formation stage $[42,43]$.

\section{Harvesting and post-harvest processing}

Oilseed crop, Brassicas are generally prone to shattering. It is more so in case of toria cultivars than in the case of mustard varieties. It is recommended that the crop should be harvested as soon as it reaches its physiological maturity i.e. when $75 \%$ siliquae on the plant turns yellowish and preferably in the morning hours when the siliquae are damp with the dew. Then the harvested plants should be kept for sun drying for 3 to 4 days. After this, the threshing should be done by running a tractor over the dried plants or by trading by the bullocks over the dried plants spread on the threshing floor. The seeds should be winnowed, cleaned and be sundried for another 3 to 4 days till the moisture content of the seed becomes 8 percent. Seed retains its viability for the next crop 
season and is also quite safe for its storage at this stage. The risk of deterioration is minimized if the mustard seed is thoroughly cleaned and dried. Duirng drying the mustard, it is critical to ensure that the seed temperature by no means exceed $52^{\circ} \mathrm{C}$ else damage to endogeneous enzymes may occur, which on processing will impair hydrolysis of the glucosinolate to the isothiocyanate, the hot principle.

Due to round shape and uniform seed size of well-matured seed lots of good varieties process of cleaning is very simple. Perforated screens, indented cylinders, ducted air and spiral separators are all effective for removing contaminants. Seed can be stored in bulk in bin made of steel, wood or in gunny bags.

\section{Conclusion}

Development of new high yielding promising varieties coupled with improved and efficient production technology, good support price and extensive adoption by farmers has caused a remarkable increase in oilseed production. However, theirs is still a gap to meet the ever-growing demand of oil in the country which can be accomplished to a large extent through better management techniques. Proper awareness towards land preparation, timely sowing, selection of better quality seeds, and so forth is required which have always been neglected in the past. To improve upon the existing yield levels obtained at farmers field site-specific nutrient management through soil-test recommendation based should be adopted. To achieve the yield targets important components like balanced NPK fertilizers along with farmyard manure and intercultural operations are the requisites. To further achieve the stable as well as increased production and productivity of rapeseed-mustard it is important to have effective measures for natural resource management, plant-water interface, and nutrient and pest management. In addition, wider extension of rapeseed-mustard cultivation to newer areas under different cropping systems will also act as an important factor in achieving the yield target. There is a wide gap between the demand and supply which results into a large scale import of fats and oils at the expense of valuable foreign exchange. Rapeseed-mustard is the most important rabi oilseed crop of Northern India grown mainly for edible oil requirement of our ever increasing population, the efforts should be made to boost the production of oilseed crops. Last but not the least, farmers of eastern Uttar Pradesh should be encouraged to adopt these integrated approaches for the better management of crop from disease and pest and achieving higher yield production.

\section{Bibliography}

1. Shekhawat K., et al. "Advances in Agronomic Management of Indian Mustard (Brassica juncea (L) Czernj Cosson): An Overview". International Journal of Agronomy (2012).

2. Anonymous. Director's report presented at the 17 th annual group meeting of rapeseed-mustard research workers held at RVSKVV, Gwalior (2010).

3. Asoodari MA., et al. "Effect of different tillage and rotation on crop performance" International Journal of Agricultural Biology 3.4 (2001): 476.

4. Rathore AL., et al. "Tillage and mulching effects on water use, root growth and yield of rainfed mustard and chickpea grown after lowland rice". Journal of Science of Food and Agriculture 78. 2 (1999): 149-161.

5. Blevins RL., et al. "Change in soil properties under no tillage". In: No Tillage Agriculture, New York, NY, USA (1984): 190-230.

6. Rosental L., et al. "Activation and regulation of primary metabolism during seed germination". Seed Science Research 24 (2014): 1-15.

7. Snapp S., et al. "Seed priming of winter annual cover crops improves germination and emergence". Agronomy Journal 100.5 (2008): 1506-1510.

8. Khan NA and Aziz SO. "Response of mustard to seed treatment with pyridioxine and basal and foliar application of nitrogen and phosphorus". Journal of Plant Nutrition 16.9 (1993): 16511659.

9. Panday D., et al. "Brassica Hybrid research in India: Status and prospects". Proceedings of the tenth international rapeseed congress Canberra, Australia.

10. Chitale $S$ and Bhambri MC. "Response of Rapeseed-mustard to crop geometry, nutrient supply, farmyard manure and interculture-a review". Ecology, Environment and Conservation 7.4 (2001): 387-396.

11. Reager ML., et al. "Yield attributes, yield and nutrient uptake of Indian mustard (Brassica juncea) as influenced by $\mathrm{N}$ levels and its split application in arid Western Rajasthan". Indian Journal of Agronomy 51.3 (2006): 213-216.

12. Tandon HLS. "Sulphur Research and Agricultural Production in India”. Fertilizer Development and Consultation Organization, 2nd edition, New Delhi, India 1986. 
13. Holmes MRJ. "Nutrition of the Oilseed Rape Crops". In: In TSI/ FAI/IFA Symposium, Applied science publishers, Essex, UK 1980.

14. Aulakh MS and Pasricha NS. "Sulphur fertilization of oilseeds for yield and quality". In: Proceedings of the TSI FAI symposium Sulphur in agriculture-S-11/3, (1988).

15. Katyal JC., et al. "Sulphur in Indian agriculture". (1997): KS$2 / 1-2 / 12$.

16. Hati KM., et al. "Irrigation and nutrient management effect on soil physical properties under soybean-mustard cropping system". Agricultural Water Management 85.3 (2006): 279-286.

17. Manohar SS. "Response of mustard (Brasica juncea (L) Czern and Coss) to irrigation, nitrogen and bio regulators". PhD Thesis, University of Udaipur, India (1981).

18. Ghosh RK., et al. "Performance of Rapeseed-mustard cultivars under various moisture regimes on the Gangetic Alluvial Plain of West Bengal". Journal of Agronomy and Crop Sciences 173.1 (1994): 5-10.

19. Gangasaran and Giri G. "Growth and yield of mustard as influenced by irrigation and plant population". Annals of Agricultural Research 7.1 (1986): 68-74.

20. Chauhan CPS and R B Singh RB. "Mustard performs well even with saline irrigation". Indian Farming 42 (2004): 17-20.

21. Majumdar DK. "Effect of supplementary saline irrigation and applied $\mathrm{N}$ on the performance of dryland seeded Indian mustard". Experimental Agriculture 31 (1995): 423-428.

22. Tomar SS and Namdeo KN. "Studies on chemical weed control in mustard". Indian Journal of Agronomy 36.1 (1991): 118-121.

23. Singh D., et al. "Infestation by weeds and their management in oilseed crop - a review". Agricultural Reviews 13.3 (1992): 163-175.

24. Castle J., et al. "Selected physiological responses of BR: a historical approach". In: S Hayat and A Ahmad (Eds) BR Bioactivity and Crop Productivity Kluwer Academic Publishers, Dordrecht-Boston-London (2003): 45-68.

25. Haubrick LL and Assmann SM. "BR and plant function: some clues, more puzzles". Plant Cell and Environment 29 (2006): 446-457.
26. Biesaga KJ., et al. "BR improves content of antioxidants in seed of selected leguminous plants". Australian Journal of Crop Science 8 (2014): 378-388.

27. Mobin M., et al. "Timing of GA3 application to Indian mustard: DM distribution, growth analysis and nutrient uptake". Journal of Agronomy 6.1 (2007): 53-60.

28. Bajguz A and Tretyn A. "The chemical characteristic and distribution of brassinosteroids in plants". Phytochemistry 62.7 (2003): 1027-1046.

29. Yopp JH., et al. "Brassinolide a growth promoting steroidal lactone. I. Activity in selected auxin bioassays". Physiologia Plantarum 53 (1981a): 445-452.

30. Yopp J H., et al. "Brassinolide in selected bioassays". 8th Proc Plant Growth Regulation Society of America (1981b): 110112.

31. Bhanu AN. "Brassinosteroids: Relevance in Biological Activities of Plants and Agriculture". Journal of Plant Science Research 35.1 (2019): 1-15.

32. Mandava NB. "Plant growth promoting brassinosteroids". Annual Review of Plant Physiology and Plant Molecular Biology 39 (1988): 23-52.

33. Clouse SD and Sasse JM. "Brassinosteroids: Essential Regulators of Plant Growth and Development". Annual Review of Plant Physiology and Plant Molecular Biology 49 (1988): 427-451.

34. Krishna P. "Brassinosteroid-Mediated Stress Responses". Journal of Plant Growth Regulators 22 (2003): 289-297.

35. Braun P and Wild A. "The influence of brassinosteroid on growth and parameters of photosynthesis of wheat and mustard plants". Journal of Plant Physiology 116 (1984): 189-196.

36. Ramraj VM., et al. "Effects of 28-homobrassinolide on yields of wheat rice mustard potato and cotton". Journal of Agricultural Sciences 128 (1997): 405-413.

37. Liang GJ., et al. "Effects of DA-6 and BR + GA3 on growth and photosynthetic rate in spinach". Acta Horticulturae Sinica 25 (1998): 356-360.

38. Hayat S., et al. "Carbonic anhydrase photosynthesis and seed yield in mustard plants treated with phytohormones". Photosynthetica 39 (2001): 27-30. 
39. Khan NA., et al. "Effect of gibberellic acid spray during ontogeny of mustard on growth, nutrient uptake and yield characteristics". Journal of Agronomy and Crop Science 181.1 (1998) 61-63.

40. Setia RC., et al. "Effect of Mixtalol on growth, yield and yield components of Indian mustard (Brassica juncea)". Plant Growth Regulation 8.2 (1989) 185-192.

41. Bakhetia, DRC., et al. "IPM for sustainable production of oilseeds". In: Oilseeds and Oils: Research and Development Needs, Indian Society of Oilseeds Research, Rai Mangala, Singh Harvir and Hegde DM (eds), Hyderabad, India (2002): 184-218.

42. Kolte SJ., et al. "Divya mustard: A useful source to create Alternaria black spot tolerant dwarf varieties of oilseed Brassicas". Plant Varieties and Seeds (UK) 13 (2000): 107-111.

43. Biswas C., et al. "Management of white rust (Albugo candida) of mustard (Brassica juncea) by altering sowing date and fungicides". Indian Journal of Agricultural Sciences 77 (2007): 626-628.

\section{Volume 3 Issue 8 August 2019}

(C) All rights are reserved by Akhouri Nishant Bhanu., et

al. 